Engineers Institute (Tel Aviv). The guide indicates the scope of these libraries and the classification used in their several catalogues, so that application for the appropriate section of the microfilmed catalogue is facilitated. The present format and pagination of the guide are cumbersome and inconvenient to the user; the bi-lingual reports by, for example, the National Research Council of Canada or the South African Council for Scientific and Industrial Research are in a much better style.

\section{Institute of Education Library, Birmingham}

THE Institute of Education Library, University of Birmingham, has issued a Supplement (No. 1, pp. 83; February 1951-March 1952) to the basic catalogue of 1951, mainly for the assistance of readers who cannot visit the Library. Items of less than 51 pages are indicated by the symbol $[\mathrm{P}]$. The entries are classificd under such heads as, for example, reference books (which cannot be borrowed), history of education, principles and philosophy of education, sociological aspects of education, national systems of education, universities and university education, adult education, vocational guidance, the curriculum, exceptional children, etc. A complete list of the Library's holdings of periodicals is included, and there is an author index.

\section{Institute of Metals: New Officers}

THE following have been elected to fill vacancies on the Council of the Institute of Metals, with effect from the annual general meeting in 1953: President, Prof. F. C. Thompson (professor of metallurgy, University of Manchester); Vice-Presidents, Major C. J. P. Ball (chairman, Magnesium Elektron, Ltd.) and Prof. G. V. Raynor (professor of metal physics, University of Birmingham); Members of Council, W. A. Baker (research manager, British Non-Ferrous Metals Research Association), J. C. Colquhoun (chairman and managing director, Manganese Bronze and Brass Co., Ltd.), E. R. Gadd (chief metallurgist, Engine Division, Bristol Aeroplane Co., Ltd.) and the Hon. John Grimston (director and general manager, Enfield Rolling Mills, Ltd.). The Council of the Institute has elected Dr. S. F. Dorey (chief engineer surveyor, Lloyd's Register of Shipping) to serve as senior vice-president for the year 1953-54, and he will be nominated for the presidency for the year $1954-55$.

\section{Colonial Service : Recent Appointments}

THE following appointments in the Colonial Service have recently been announced: D. F. Davidson (assistant conservator of forests, Cyprus), senior assistant conservator of forests, Cyprus ; J. K. Ross (assistant conservator of forests, Sierra Leone), assistant conservator of forests, Nigeria; J. M. Waterston (senior botanist, Nigeria), principal research officer, Agricultural Department, Nigeria; J. D. Birkett (senior veterinary officer, Nigeria), director of veterinary services, Sierra Leone; G. F. Darnell, agricultural officer, Federation of Malaya; G. E. Dixon, plant breeder, Kenya; P. Greening, agricultural officer, Northern Rhodesia; W. G. Plaistowe, agricultural officer, Nyasaland; R. M. Sister, entomologist, West African Cocoa Research Institute, Gold Coast ; M. E. H. Vickers, agricultural officer, Kenya ; P. E. Wheatley, agricultural entomologist, Kenya ; R. C. Norris, chemist, Federation of Malaya; J. A. B. Stewart, geologist, Somaliland
Protectorate ; L. A. J. Williams, geologist, Kenya ; A. D. McKelvie, plant physiologist, West African Cocoa Research Institute, Gold Coast ; G. R. Robson, scientific officer, Trinidad (seismological observer in charge of recording station, Windward and Leeward Islands) ; D. J. Taylor, entomologist, West African Cocoa Research Institute, Gold Coast; R. Wilson, veterinary officer, Somaliland Protectorate; P. H. Gulliver, sociologist, Sociological Research Provincial Administration, Tanganyika; H. F. Lamprey, biologist, Game Department, Tanganyika; N. G. Shaw, assistant conservator of forests, North Borneo ; R. Tavener-Smith, geologist, Northern Rhodesia; G. Webbe, entomologist, Medical Department, Tanganyika; E. Wigura, computer, Surveys and Town Planning Department, Tanganyika.

\section{Announcements}

Prof. M. von LAUE, who will be addressing a meeting of the Physical Society at 5 p.m. on October 29 at the Science Museum, South Kensington, London, S.W.7, will first present the Max Planck Medal for 1952 to Prof. P. A. M. Dirac on behalf of the Association of German Physies Institutes.

Mr. N. D. RiLEY, keeper of entomology in the British Museum (Natural History), is relinquishing the editorship of The Entomologist, a post he has held for thirty-one years, and will be succeeded in the new year by Mr. D. Leston. The journal is to be increased in size and widened in scope to include all aspects of pure and applied entomology ; all inquiries regarding it should be directed to the editor at 44 Abbey Road, London, N.W.8.

THE National Science Foundation (2144 California Street, N.W., Washington 25, D.C.), in co-operation with the University of Chicago, is organizing a conference on the "Abundance of the Elements", to be held at the Yerkes Observatory, Williams Bay, Wisconsin, during November 6-8. The conference will bring together some forty leading astronomers, chemists, geochemists and physicists, drawn from university, industrial and government research organizations, who will consider the effect of recent research in stellar and terrestrial measurements on current theories of the abundance of elements in the universe. It is hoped that, as a result of this conference, fresh light will be brought to bear on the origin and material limits of the universe.

A FELLOWSHIP and a number of scholarships for work on arctic or sub-arctic research are being offered jointly by McGill University and the Arctic Institute of North America, with the financial support of the Carnegie Corporation of New York. The fellowship, which is worth 4,000 dollars, is for a senior research worker who has completed his studies in the field and requires a year's residence in a centre of learning to prepare his results or acquire specialized knowledge. The scholarships are normally tenable for one year, being worth on the average 750 dollars with 1,500 dollars field expenses, and are for graduates intending to undertake active field research. Further information regarding these awards can be obtained from the Carnegie Arctic Program, Arctic Institute of North America, 3485 University Street, Montreal, P.Q. Applications must be sent in by January 1, 1953, except that scholarship candidates not intending to do field-work in the summer of 1953 need not send their applications until April 1, 1953. 